輪状膵に伴う膵 intraductal papillary mucinous tumor（IPMT）の 1 例

\author{
佐賀大学一般 - 消化器外科 \\ 平木将紹大塚隆生北原賢二 \\ 田村 智章 本山健太郎 宮㠃耕 治
}

症例は66歳, 男性. 全身倦急感, 肝機能障害の検查目的に行われたCT で脺頭部に $40 \times$ $35 \mathrm{~mm}$ の真胞性病変を指摘され, 当科へ紹介された。精査の結果, 輪状膵に伴う IPMT と診断し, 脺頭十二指腸切除術を施行した。輪状膵に伴ったIPMT の報告例はなく, 非 常に稀な症例と思われた。輪状膵とIPMT の因果関係抢よび手術適応につき文献的考察 を加え報告する。

索引用語 : annular pancreas, intraductal papillary mucinous tumor

\section{緒 言}

輪状腫は，膵組織の一部が十二指腸下行脚を輪状に 取り巻く先天性の発生異常であり, 急性膵炎, 十二指 腸狭窄のため手術適応となることがしばしばある。一 方, intraductal papillary mucinous tumor (以下 IPMT と略記）は膵管上皮由来の粘液産生性膵腫瘍で あり，高齢者男性の脺頭部を中心に発生することが多 い，拡張した主膵管もしくは分枝膵管内に, 粘液を産 生する腫瘍細胞が乳頭状に増殖し, 主膵管と交通する ことが多い. 主脺管型であるものや，末梢型でも黄胞 径がきいもの, 襄胞内結節隆起を認めるもの, 主膵 管拡張を認めるものは切除の対象となる.今回，われ われは, 輪状膆にIPMT が合併した非常に稀な症例に 対し, 勝頭十二指腸切除を行ったので, 文献的考察を 加え報告する。

患者：66歳, 男性.

主訴：全身供意感.

現病歴：2001年 7 月より全身僚怠感を認めた。 2002 年 8 月, 近医で肝機能障害を指摘され, 外来で肝庇護 療法を受けていた。同年11月腹部 CT を施行され, 膵 頭部に喜胞性病変を指摘され，同年12月18日，精查・ 加療目的に当科紹介入院となった.

既往歴：40歳代に胃潰場の診断で, 幽門側胃切除術

2004年11月24日受付 2005 年 1 月 27 日採用

〈所属施設住所〉

=849-8501 作賀市鍋島 5-1-1
（Billroth-II再建）を施行された.

入院時身体所見：眼瞼結膜に貧血なく，眼球結膜に 黄㾝を認めなかった。上腹部正中に手術痕を認めた。 腹部は平坦で軟らかく、腫瘤は触知されなかった。

入院時血液所見: 肝・胆道系醭素の上昇, CA19-9, SPAN-1の軽度上昇を認めた（Table 1)。

\section{画像所見}

腹部超音波：主膵管は径 $4.5 \mathrm{~mm}$ に㹡張していた。膵 頭部は術後の痹着のため描出困難であった。

上部消化管造影：幽門側胃切除後の状態で, 十二指 腸下行脚に全周性の狭窄像を認めた。狭窄部粘膜面に 異常はなく，壁外性病変が疑われた（Fig. 1).

腹部 CT：主膵管は約 $5 \mathrm{~mm}$ に拡張していた（Fig. 2a）。膵鈎部から頭部にかけて $40 \times 35 \mathrm{~mm}$ の多烡胞性

Table 1 Result of blood test at the admission

\begin{tabular}{|c|c|c|c|c|}
\hline WBC & 6,400 & $\mu \mathrm{l}$ & AMY & $\mathrm{IU} / 1$ \\
\hline $\mathrm{RBC}$ & $\underline{421 \times 10^{4}}$ & $/ \mu 1$ & $\mathrm{Ch}-\mathrm{E}$ & $\mathrm{IU} / 1$ \\
\hline $\mathrm{Hb}$ & $\underline{12.1}$ & $\mathrm{~g} / \mathrm{dl}$ & & \\
\hline \multirow[t]{2}{*}{ Plt } & $18.2 \times 10^{4}$ & $/ \mu 1$ & CEA & $2.6 \mathrm{ng} / \mathrm{ml}$ \\
\hline & & & CA19-9 & $\mathrm{U} / \mathrm{ml}$ \\
\hline AST & $\underline{60}$ & $\mathrm{IU} / 1$ & DUPAN2 & $\mathrm{U} / \mathrm{ml}$ \\
\hline ALT & 31 & $\mathrm{IU} / 1$ & SPAN-1 & $\mathrm{U} / \mathrm{ml}$ \\
\hline $\mathrm{T}-\mathrm{Bil}$ & $\underline{1.1}$ & $\mathrm{mg} / \mathrm{dl}$ & Elastase & $\mathrm{ng} / \mathrm{dl}$ \\
\hline D-Bil & 0.1 & $\mathrm{mg} / \mathrm{dl}$ & & \\
\hline ALP & $\underline{613}$ & $\mathrm{IU} / 1$ & HBV antigen & negative \\
\hline$\gamma \mathrm{GTP}$ & $\underline{377}$ & $\mathrm{IU} / 1$ & $\mathrm{HCV}$ antibody & negative \\
\hline
\end{tabular}




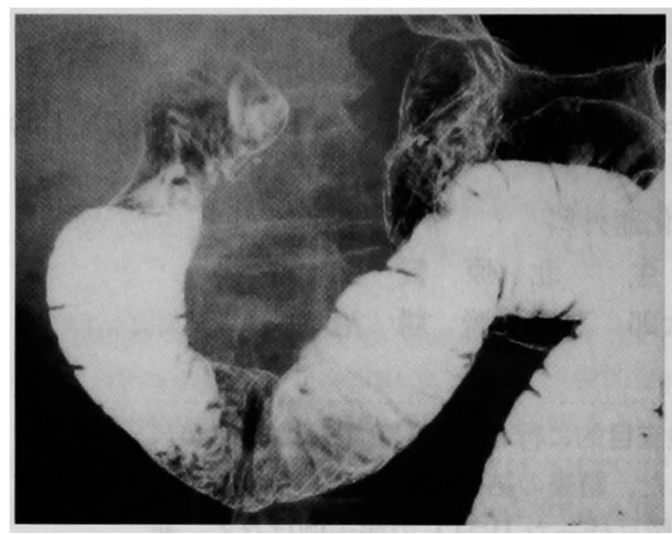

Fig. 1: Upper GI series demonstrating circular thickness of the $2^{\text {nd }}$ part of the duodenum.
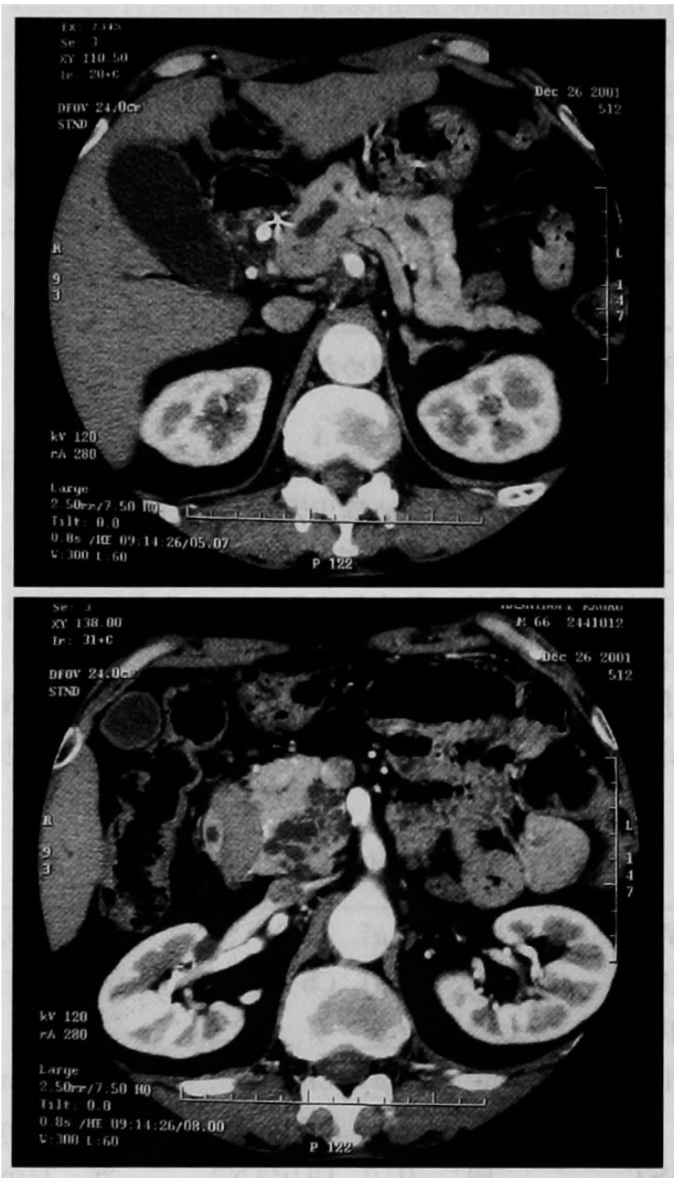

Fig. 2 : Enhanced computed tomography showing multiple cystic lesion at the head of pancreas (a), and dilated pancreatic duct, $5 \mathrm{~mm}$ in diameter (b).

$\frac{a}{b}$

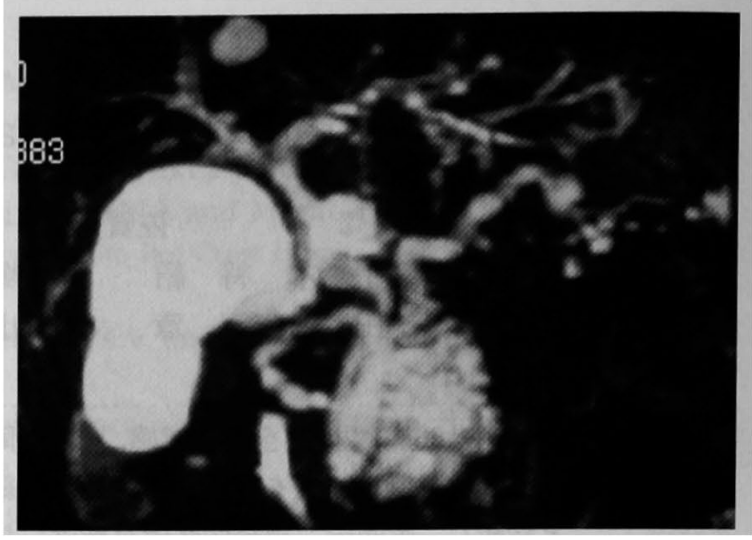

Fig. 3 : Magnetic resonance cholangiopancreatography demonstarting multiple cystic lesion at the head of pancreas and annular duct.

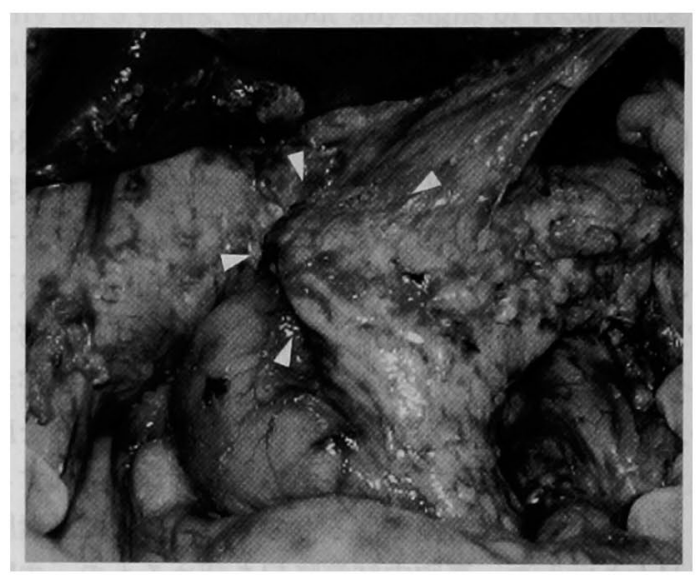

Fig. 4 : Operative findings. Pancreatic tissue surrounded $2^{\text {nd }}$ part of the duodenum.

病変を認め (Fig. 2b)，この襄胞性病変と主膵管には 連続性が疑われた。 また，罴胞内に明らかな充実成分 を認めなかった。十二指腸下行脚を取り囲む膵組織と 等嶩度の構造物を認め, 輪状膵が疑われた。

MRCP : 膵鈎部, 頭部に $40 \times 35 \mathrm{~mm}$ のぶどうの房状 の多発意胞性病変を認め,この寠胞性病変とWirsung 管との交通が疑われた。脺管は十二指腸下行脚を取り 囲むように走行し，輪状膵の所見であった，輪状脺の 膵管はWirsung 管と交通しており，湯村分類 I 型 ${ }^{1} に$ 相当した。また，主膵管の拡張もみられた（Fig.3）。 画像上，膵胆管合流異常の所見は認めなかった。 ERCP, EUS は Billroth-II再建後であり, Vater 乳頭 部まで内視鏡の挿入が困難であった。

各種画像所見より IPMTが強く疑われた. Billroth 


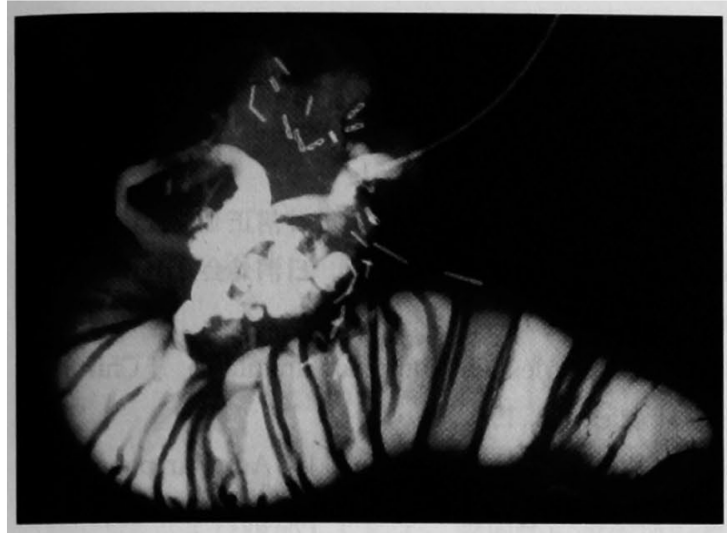

Fig. 5 : Resected speicemen with injection of the contrast medium to the main pancreatic duct, showing communication between annular duct, main pancreatic duct and cystic lesion.

-II再建術後のため, EUS, ERCP が施行できず，㹡張 膵管内の結節状隆起病变の評価ができなかったが，腫 場径が $40 \mathrm{~mm}$ であり，輪状膵に伴うIPMT と診断し， 2002年 1 月28日に手術を施行した。術中所見では，腹 側脺が十二指腸右側から前面にせり出し，十二指腸全 周を脺が取り巻いており，輪状脺であることが確認て きた (Fig. 4)。膵鈎部の腹側脺は弾性軟で, 塞胞性病 変の存在が窥えた。膵頭十二指腸切除術および Rouxen-Y 法再建を施行した. 切除膵の標本造影では, 十二 指腸下行脚を取り巻く膆管像が得られた。また，主脺 管と塞胞性病変に交通を認めた（Fig.5)。輪状膵導管 は後方から Wirsung 管へ開口しており，MRCP と同 様に湯村分類 I 型と診断した。

病理組織学的検査：病変は分枝脺管を主座とし，一 部主膵管に及んでおり，ムチンを含んだ核の腫大した 軽度異型性の腺腫の像を認め, intraductal papillary mucinous adenoma with mild atypia；混合型と診断 した (Fig. 6).

術後経過は良好で, 第29病日に退院した。術後 1 年 9 カ月を経過したが, 現在無再発生存中である.

\section{考 察}

輪状膵は, 膵頭部組織の一部が十二指腸下行脚を環 状に取り囲む先天性発育異常である. 発生成因は Lecco 説' ${ }^{2}$ が最も支持されており, 胎生期に, 腹側原基 右葉が十二指腸の前壁に疮着したまま回転発育したも のと考えられている.その発症頻度は非常に稀で, 剖 検, 手術例で 10 万人あたり $4.5 \sim 15$ 人 $^{3-\text { (-) }}$ ，男女比は $1: 0.54 \sim 0.6^{4,7)}$ と男性に多く，発症年齢は $40 \sim 50$ 歳

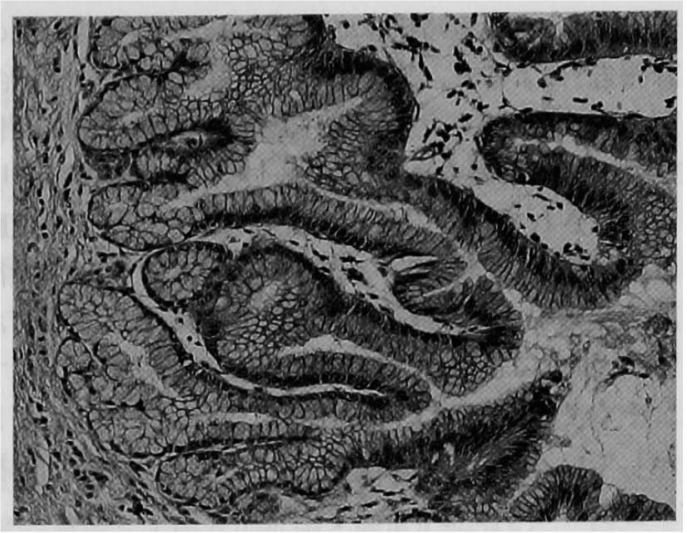

Fig. 6: Microscopic appearance of pancreatic tumor $(\mathrm{H} . \mathrm{E}$ stain. $\times 200)$ demonstrating adenoma with mild atypia in the epithelium of the branch of pancreatic duct.

代に多いと報告されている4). 輪状脺の合併症として は, 消化性漬疱, 胆石症, 膵炎があり, 無症状である 場合には治療を必要としないが, 症状がみられる場合 に手術が考虑される。本症例ては，一時的な肝機能障 害を認めたが,これはIPMT が産生する粘液による一 時的な胆汁㰫滞によるものと考えられた。また消化性 潰瘍の術後状態であるが，他に輪状脺に特徵的な症状 を認めず，輪状膵そのものに対する手術適応よりも， IPMTに対しての手術適応が最も考慮されるべき症 例と考えられた。

本症例は, Billroth-II再建後であるため, ERP, EUS が手技的に困難であった．腹部エコーでも塞胞性病変 の描出ができなかったか， CT ゃ MRCP 上，基胞内隆 起病変を示唆する所見を認めなかった。しかし，襄胞 径が $40 \mathrm{~mm}$ で, 主膵管の拡張を認めたことから，切除 の適応があると判断し，充分なインフォームドコンセ ントのもと手術を行うこととした。

術式に関しては, 輪状膵を合併しているという特殊 性を考虑する必要があった。積極的に悪性を疑う所見 はなく, 十二指腸温存膵頭部切除術, もしくは脺頭部 + 輪状膵切除術も術式として考慮した。しかし，輪状膵 切除術後には，膵液瘜・脺炎などの合併症をおこしゃ すいこと，十二指腸壁内に脺組織が入りこんでいるた め手技的困難をきたすこと，また輪状膵の将来的な徳 影響を考慮して膵頭十二指腸切除術を選択した。

本症例において IPMT の発生が, 輪状膵あるいは胃 切除術と関係がある可能性は低いと考えているが，輪 状脺あるいは胃切除と膵腫㿠との因果関係を示唆する 
報告もある.成人型輪状脺における本邦報告例151例の

集計報告 ${ }^{8}$ によると，悪性腫場の合併は20例 (13.2\%) に認められ，このうち15例 $(75 \%)$ が膵胆道系の悪性 腫瘍であったと報告されている。その発症機序は，明 らかにはされていないが，輪状膵と膵・胆道系悪性腫 暍との因果関係が示唆されている。また，胃切除術後 長期間経過すると膵癌の発生が増加するとの報告もあ り $^{9 \text { (11), 世古口ら }}{ }^{111}$ は, 胃切除の既往歴を有する症例で は,そうでない症例よりも脺管上皮の変化が強いこと を示している．この問題点については，今後更なる検 討が必要であると思われる。

\section{結 語}

輪状膵に伴う膵 IPMTの 1 例を報告した. 画像診断 の進步伴い，今後このような症例が発見される機会が 增えてくる可能性があるが，それぞれの病態を十分に 評価した上で，切除を含めた治療方針を立てていく必 要がある。

\section{謝 辞}

稿を終えるにあたり，本症例の病理診断に御指導いただ きました，佐賀大学病因病態科学講座，森 大輔先生に深謝 申し上げます。

\section{文献}

1）湯村正仁, 荒木京二郎, 成末允勇他：環状膵 成 人謤状膀の 1 例と本邦報告例の集計。日臨外会誌 $37: 468-480,1976$

2) Lecco TM:Zur Morphologie des Pankreas Annulare. Sitzungsb Wien Akad Wiss $119: 391$
$-406,1910$

3) Vasconcelos E, Sadek HM : Pancreas annular produzindo estenose duodenal. Rev Bras Gastroenterol 1:535-551, 1949

4）戸田耕太郎, 広瀬周平, 筒井信正他：輪状䏽が併 存した脺頭部癌の切除例。日消外会誌 $16: 1549$ $-1553,1983$

5) Thedordes $T h$ : Pancreas annulaire. J Chir 87 : 445-462, 1964

6) Ravitch MM, Wood AC Jr : Annular pancreas. Ann Surg 132 : 1116-1127, 1950

7) Kiernan PD, ReMin SG, Kiernan PC, et al: Annular Pancreas. Arch Surg 115 : 46-50, 1980

8) Ogawa $S$, Seshimo A, Shirotani $N$, et al : A Case of Annular Pancreas Complicated with Carcinoma of the Bile Duct. J Tokyo Wom Med Univ $70: 29-35,2000$

9) Offerhaus GJ, Giardiello FM, Moore GW, et al : Partial gastrectomy:a risk factor for carcinoma of the pancreas? Hum Pathol 18 : 285288, 1987

10) Van Rees BP, Tascilar M, Hruban RH, et al : Remote partial gastrectomy as a risk factor for pancreatic cancer:potential for preventive strategies. Ann Oncol $10: 204-207,1999$

11）世古口努, 松本英一，伊藤史人他：傽癌における 胃切除既往の意義.消化器科 $21: 407-414,1995$

\title{
A CASE OF INTRADUCTAL PAPILLARY MUCINOUS TUMOR (IPMT) ASSOCIATED WITH ANNULAR PANCREAS
}

\author{
Masatsugu HIRAKI, Takao OHTSUKA, Kenji KITAHARA, \\ Tomoaki TAMURA, Kentaro MOTOYAMA and Kohji MIYAZAKI \\ Department of Surgery, Saga University Faculty of Medicine
}

A 66-year-old man was admitted to the hospital because of general fatigue and liver dysfunction. Computed tomography and magnetic resonance cholangiopancreatography demonstrated a cystic lesion in the pancreas head, $40 \times 35 \mathrm{~mm}$ in diameter, and an annular pancreas. The patient underwent a pancreatoduodenectomy with the diagnosis of intraductal papillary mucinous tumor (IPMT) with annular pancreas. To our knowledge, this is the first case report of IPMT associated with annular pancreas. We discussed relationships between IPMT and annular pancreas, and operative indication for such cases. 